\title{
A white feathered area on the forehead is more common in hybrids of Greylag Goose Anser anser and Greater Canada Goose Branta canadensis than in the parent species
}

\author{
Ett vitt befjädrat område på huvudet närmast näbben är vanligare på hybrider \\ mellan grågås Anser anser och kanadagås Branta canadensis än det är på \\ föräldraarterna
}

C. G. GUSTAVSSON

Abstract

This study evaluated prevalence and extent of white areas on heads of Greylag Goose $\times$ Greater Canada Goose hybrids. A white area which bordered the bill and then to various degrees extended over the forehead was found in 17 out of 20 hybrids. This was significantly more common in the hybrids than in the parent species. The white areas in the hybrids were also significantly larger than in those 82 out of 191 adult Greylag Geese which had some amount of white area. There were too few Greater Canada Geese with a white area outside the normal pale cheek patch to make a meaningful similar quantitative comparison also with them. No white area was seen in the three presumed 1st Calendar year hybrids but when two of them were seen again in September of the 2nd Cy there were some pale feathers that were interpreted as the beginning of white areas. The white areas in hybrids are therefore regarded to be adult features which like in several pure Anser species begin to develop during the 2nd Cy.

C G Gustavsson,

Blidvädersvägen 6B 1tr, 22228 Lund, Sweden.

Email:CG@Gustavsson.se

Received 1 November 2010, Accepted 15 March 2011, Editor S. Svensson

\section{Introduction}

A white area over the forehead is a characteristic feature of some Anser species such as Greater White-fronted Goose Anser albifrons and Lesser White-fronted Goose Anser erythropus (Madge \& Burn 1988). Also several other Anser species including Greylag Goose Anser anser may have a thin white border next to the bill (Figure 1) but in my experience rarely any larger white area like those in Figure 2 and (Gustavsson (www). In Greater Canada Geese Branta canadensis, anomalous white areas of a somewhat different type may be seen on the heads in a few percent of the birds (Hanson 1949, Figures 3-4). Finally, in my experience a white area on the forehead is very commonly found in Greylag Goose $\times$ Greater Canada Geese hybrids (Figures 5-6). This may lead to speculation about involvement of Greater White-fronted Goose and to misclassifications.

The aim of this study was to compare the prevalence and extent of white areas on the forehead in Greylag Goose $\times$ Greater Canada Goose hybrids with what may be seen in the parent species.

\section{Material and methods \\ Material}

All twenty Greylag Goose $\times$ Greater Canada Goose hybrids in my photo archive were compared with photos of 191 Greylag Geese and with two separate materials comprising a total of 125 Greater Canada Geese. Eighteen of the hybrids are numbers 1-18 in a previous article (Gustavsson 2010). Individuals 4-6 were considered to be 1st Cy (Calendar year) birds. All hybrids in the study material corresponded to the description of Greylag Goose $\times$ Greater Canada Goose hybrids by Randler (2001). Parentage was presumed but not proven e.g. by genetic analysis. Two somewhat similar hybrids were considered to result from other species combinations. One very small bird with a short bill was classified as a Lesser Canada Goose $\times$ Greylag Goose hybrid (Figure 8). Another hybrid had the size of a Greater Canada Goose, dark wine red bill, large white head and neck areas, pale-fringed tertials, pale-tipped tail feathers and pink legs - it was presumed to be a Snow Goose $\times$ Greater Canada Goose hybrid. The Greylag Geese were moulting 

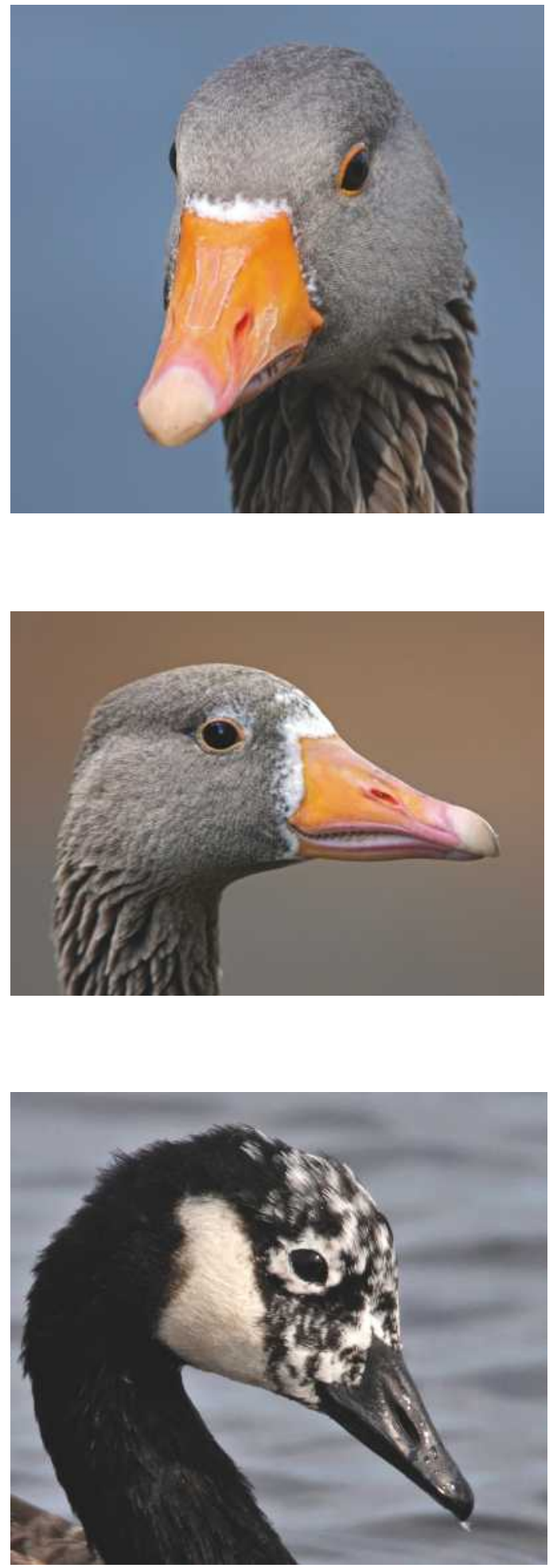

Figure 1. Among the 191 Greylag Geese in the study population, this is one of the individuals with the largest extent of white border to bill though still only Class 1. 6 June 2010 . Bland de 191 grågässen i studiepopulationen är detta en av individerna med den största utbredningen av vitt vid näbbroten, fast ändå bara Klass 1. 6/6 2010.

Figure 2. Among all Greylag Geese in my photo archive, this is one out of the two with the largest extent of white, Class 2. The other one is (Gustavsson (www). In both birds, there is also some amount of white around the eye and up over the forehead. 16 June 2008.

Bland alla grågäss i mitt fotoarkiv är detta en av de två med den största utbredningen av vitt vid näbbroten, Klass 2. Den andra är (Gustavsson (www). På båda fåglarna finns också ett visst mått av vitt runt ögat och upp över pannan. 16/6 2008 .

Figure 3. Greater Canada Goose with one out of two different patterns of white areas on heads in this study - a spotted mixture of white and black feathers which often is most pronounced between bill and eye as well as around the eye. Considered as Class 3 extension. 12 September 2009.

Kanadagås med det ena av två olika mönster av vitt på huvudet $i$ studiematerialet - en fläckig blandning av vita och svarta fjädrar som ofta är mest uttalad mellan näbben och ögat liksom runt ögat. Bedömd som Klass 3 utbredning. 12/9 2009. 
Figure 4. Greater Canada Goose with the other pattern of white areas on heads in this study - a more Barnacle Goose like pale forehead area which was most pronounced in this individual. This picture was taken 17 September 2010 but the bird also belonged to the 95 Greater Canada Geese which were counted 20 August 2010.

Kanadagås med det andra mönstret av vitt på huvudet $i$ studiematerialet - ett mönster som mera liknar det hos vitkindad gås och som var mest uttalat på denna individ. Bilden togs 17/9 2010 men fågeln tillhörde de 95 kanadagäss som räknades 20/8 2010 .

Figure 5. Typical pattern of white areas on the head in Greylag Goose x Greater Canada Goose hybrids. There is a white border next to the bill reminding on the distribution of white in Greylag Geese and in addition white spotting reminding on what is seen in some Greater Canada Geese such as the one in Figure 3. Classified as Class 2 extension. This bird has been seen at the same location at least for the last three years and should be at least 4th Cy. 17 September 2010.

Typiskt mönster av vita områden på huvudet på kanadagås $x$ grågås hybrider. Det finns en vit kant längs näbben vilket påminner om utbredningen hos grågås, men även vitfläckighet som påminner om det man kan se på en del kanadagäss, t ex den i Figure 3. Bedömd som Klass 2 utbredning. Denna fågel har setts på lokalen de senaste tre åren och borde vara minst 4k. 17/9 2010.

Figure 6. Hybrid Greylag Goose x Greater Canada Goose with a large extension of white which was considered as Class 3. 12 September 2009.

Hybrid grågås $x$ kanadagås med stor utbredning av vitt som bedömdes som Klass 3. 12/9 2009.
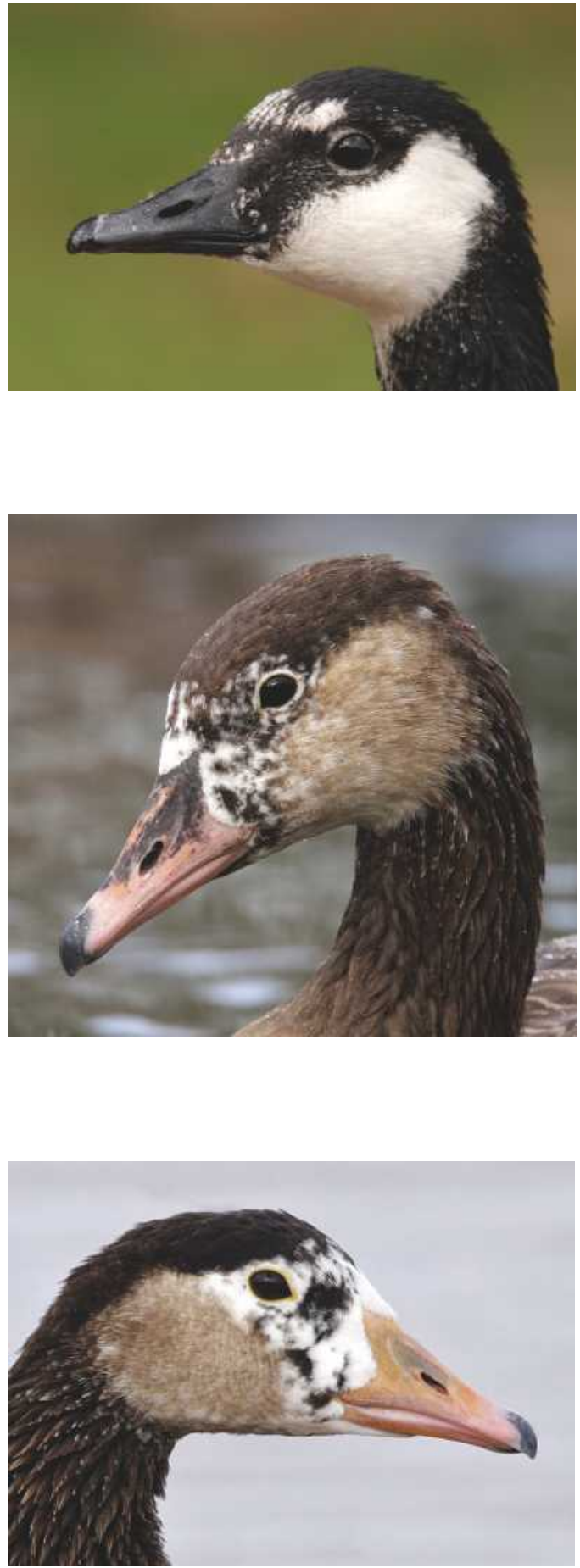
adult birds which were photographed in Malmö, Sweden on 6 June 2010 and they comprised all the birds I could approach enough for a close-up head photo. The Greater Canada Geese were 30 individuals that were collected in Scania, Sweden, in the winter 2009-2010 for genetic and morphological analysis and 95 individuals which were studied by a combination of binocular observation and photography in Skövde, Sweden on 20 August 2010. An absolutely certain photo documentation of all individuals could not be made in the 95 Greater Canada Geese because the birds were continuously moving. However, repeated visual evaluation showed no further birds with white head areas in addition to the four photo-documented individuals.

\section{Methods}

All hybrids and Greylag Geese were photographed (head portraits) and white components on the foreheads were classified according to an arbitrary scale which was constructed for this study: Class $0=$ absent, Class $1=$ minimal-to-small, Class $2=$ moderate, and Class $3=$ extensive (Figures 1-3 and 5-6). The same scale was applied also to the Greater Canada Geese even though the location of white areas was somewhat different in them. As an additional analysis of white area extent, the largest amount of white in any of the Greylag Geese was used for comparison with the hybrids, in which the white areas were then subdivided as smaller than or similar to versus larger than the maximal extent of white in the Greylag Geese (Figure 1).

\section{Statistical analysis}

The study hypotheses were that: 1 . White areas on the forehead are more common in Greylag Goose $\times$ Greater Canada Goose hybrids than in the parent species and 2. The amount of white in birds with such white areas is on average larger in hybrids than in Greylag Geese.

The hybrids were compared with the two parent species. Presence vs. absence of white areas on foreheads was analysed by Fischer's exact test. In birds with any amount of white area, a quantitative comparison of Classes 1 to 3 in hybrids and in Greylag Geese was done by Mann-Whitney U-test and a qualitative comparison with the largest extent of white in Greylag Geese by Fisher's exact test. Two-sided p-values $<0.05$ were considered statistically significant.

\section{Results}

Presence or absence of any amount of white on the forehead in the hybrids and in both parent species is shown in Table 1. Such white areas were thus much more common in the hybrids than in the parent species, especially more common than in the Greater Canada Geese.

In those birds which had a white area, I then also made quantitative comparisons. The extent of white according to the scale Class $1 /$ Class 2 / Class 3 was distributed in the hybrids as $5 / 8$ / 4 individuals and in the Greylag Geese as 82 / 0 $/ 0(\mathrm{p}<0.001)$. In a separate analysis, the largest

Table 1. Prevalence of a white area of any size on the forehead (outside the pale cheek area in hybrids and Greater Canada Geese.

Förekomst av någon form av vitt område framtill på huvudet (utanför kindfläckarna på hybriderna och kanadagässen).

\begin{tabular}{lcc}
\hline $\begin{array}{l}\text { Species } \\
\text { Art }\end{array}$ & $\begin{array}{c}\text { White area } \\
\text { (yes/no) } \\
\text { Vitt område } \\
\text { (ja/nej) }\end{array}$ & $\begin{array}{c}\text { p-value for } \\
\text { difference to hybrids } \\
\text {-värde för skillnad } \\
\text { gentemot hybriderna }\end{array}$ \\
\hline $\begin{array}{l}\text { Hybrids Greylag Goose } \times \text { Greater Canada Goose }(\mathrm{n}=20) \\
\text { Hybrider grågås } \times \text { kanadagås }(n=20)\end{array}$ & $17 / 3$ & \\
$\begin{array}{l}\text { Greylag Goose, adults Grågås, adulta }(\mathrm{n}=191) \\
\text { Greater Canada Goose Kanadagås }(\mathrm{n}=30)^{*}\end{array}$ & $82 / 109$ & $<0.001$ \\
Greater Canada Goose Kanadagås $(\mathrm{n}=95)^{* *}$ & $1 / 29$ & $<0.001$ \\
\hline
\end{tabular}

* Material collected for genetic analysis. Material insamlat för genanalys.

** Field observation by binocular and camera. Fältobservation med kikare och kamera. 
Figure 7. Greater Canada Goose with an extensive white component on head and neck, far beyond the limit for Class 3. 12 September 2009.

Kanadagås med ett utbrett vitt inslag på huvud och hals, långt förbi gränsen till Klass 3. 12/9 2009.

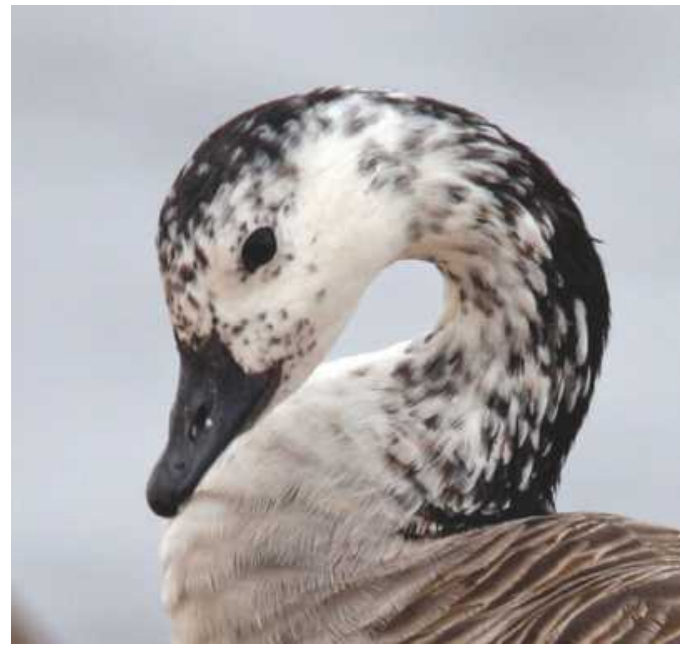

at several locations and the white component has then often been most pronounced between the bill and the eye as well as around the eye. It has in some cases also extended down the neck (Figure 7). When I reviewed the photos of Greater Canada Geese with white areas on the head or neck at Artportalen (www), virtually all birds with white areas outside the normal cheek patch seemed to be of this type. However, among the 95 Greater Canada Geese in this study, there was also one bird with a different and more Barnacle Goose like head colour distribution (Figure 4) and in its company also a bird with a small pale area high above the forehead. On a later visit to the same location, the number of Canada Geese had increased and then there was also a large bird with white spots above the eyes. These types of head colour distribution may be seen in pictures of birds which are considered to be Giant Canada Geese Branta canadensis maxima, e.g. those by Harteman (www).

In all hybrids and Greylag Geese which had a white area, this was without exception bordering the bill with different extension onto the forehead; the white rim was however clearly broader in the majority of hybrids. In most hybrids, there were also spotted areas with some similarity to the spotted type of white areas seen in Greater Canada Geese (Figures 3 and 5-6). It also seemed that the distribution of white areas in individual birds was rather constant over years. What I presume to be the same individual is shown in a picture by Södercrantz (www) and in Figure 6. These pictures were taken at the same location in the first week of Sep- 

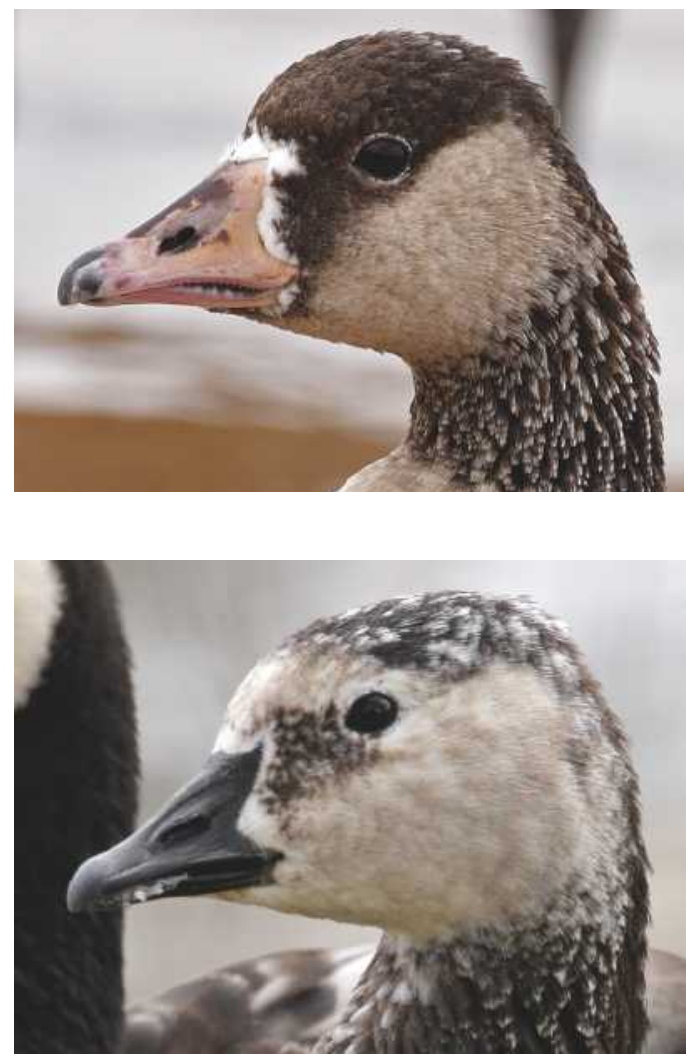

tember but four years apart. This is then the longest follow-up time for hybrids in this material.

The study was restricted to Greylag Goose $x$ Greater Canada Goose hybrids, partly because these species and the cross between them are relatively common and thus available and partly because both parent species are usually perceived as not having white forehead areas. In several other Anser $\times$ Branta hybrids, one or both parent species have white foreheads. Examples of such species which often hybridise are Lesser White-fronted Goose $A n$ ser erythropus and Barnacle Goose Branta leucopsis. However, in autumn Greylag Goose $\times$ Barnacle Goose hybrids have two-coloured cheek patches with a white area over the forehead and a more Greylag Goose like colour on the rest of the cheek patch area (Gustavsson 2009). Other examples of Anser $\times$ Branta hybrids which may have white areas next to the bill are Greylag Goose $\times$ Lesser Canada Goose Branta hutchinsii (Figure 8) and Snow Goose Anser caerulescens $\times$ Barnacle Goose (Figure 9). A white area adjacent to bill is thus not specific for the
Figure 8. Presumed Greylag Goose x Lesser Canada Goose hybrid with a small amount of white surrounding the bill, Class 1. 12 September 2009.

Förmodad grågås $x$ dvärgkanadagås hybrid med liten mängd vitt vid näbbroten, Klass 1. 12/9 2009.

Figure 9. Presumed Snow Goose x Barnacle Goose with an all-white margin around the base of the bill but also a general admixture of white spotting which may be a direct heritage from a white Snow Goose parent. Captive 3rd Cy bird. 20 April 2010.

Förmodad snögås $x$ vitkindad gås med en helvit kant runt näbbasen men även ett generellt inslag av vita fläckar som kan vara ett direkt arv från en vit snögåsförälder. I fångenskap, 3k. 20/4 2010.

studied Anser $\times$ Branta parent combination but can be found in several crosses between an Anser and a Branta species. This should have implications for field ornithologists - a white area next to the bill cannot automatically be taken as indicating Whitefronted Goose parentage.

In a previous article I showed that coloured tail coverts are common in hybrids from a large number of Anser $\times$ Branta species combinations despite all-white coverts in adult birds of the parent species (Gustavsson 2010). That finding was believed to possibly be a modified juvenile feature which is retained in adulthood. The present study showed that a white feathered area adjacent to the bill is common in Greylag Goose $\times$ Greater Canada Goose hybrids and more common than it is in either of its parent species. Contrary to the previous study with retained juvenile features, the findings in the present study are those of features which are typical for adult Anser birds such as Greater and Lesser White-fronted Goose. In these, the white area develops during the $2^{\text {nd }} \mathrm{Cy}$ and so does the white rim 
Figure 10. Greylag Goose x Greater Canada Goose hybrid, $1^{\text {st }} \mathrm{Cy}, 14$ October 2009. No white areas on the head at that age, thus Class 0.

Grågås x kanadagås hybrid, $1 \mathrm{k}, 14 / 10$ 2009. Inga vita områden på huvudet vid denna ålder, därför Klass 0 .

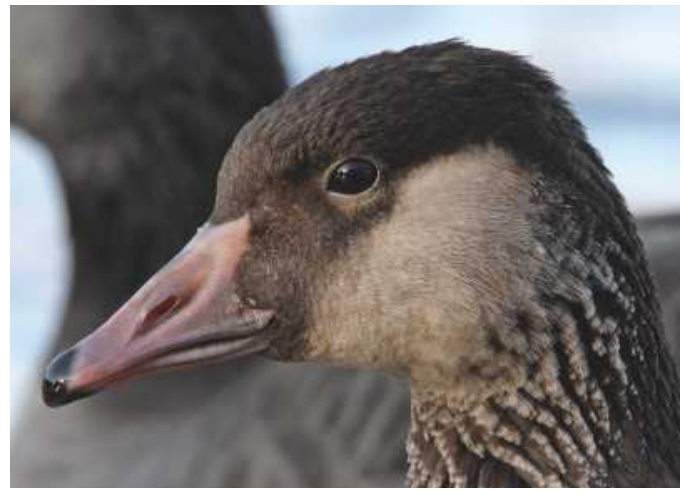

Figure 11. Almost certainly the same Greylag Goose x Greater Canada Goose individual as in Figure 10, 17 September 2010 and thus 2nd Cy. There were then some white feathers near the bill and below the eye, Class 1 .

Nästan säkert samma grågås $x$ kanadagås individ som på Figure 10, 17/9 2010 och således 2k. Det hade då tillkommit några vita fjädrar nära näbben och nedom ögat, Klass 1 .

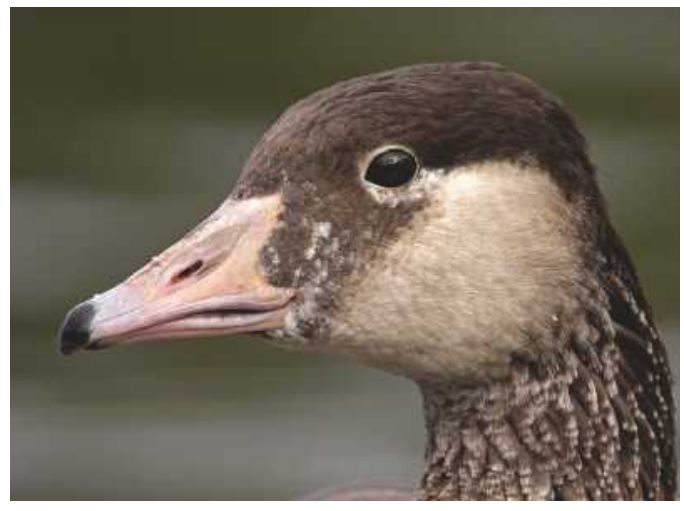

\section{Acknowledgements}

The author is indebted to Kent-Ove Hvass for showing the hybrids in Skövde, to Carl-Gustaf Thulin for constructive criticism and to Dave Appleton for checking the manuscript. sumed 1st Cy hybrids had any white (Figure 10) but when two of them were sighted again during the $2^{\text {nd }} \mathrm{Cy}$, on 17 September 2010, both had some small pale spots near the base of their bills (Figure 11). I interpreted this as an adult feature under development in those two birds. For that reason and based upon an impression that the larger white areas also bear some resemblance to what may be seen in Greater Canada Geese (Figure 3), I suggest that the pale forehead area in the hybrids may be seen as a combination of the white areas around the bill which may be found with high prevalence in several Anser Geese (and in all adult hybrids in this study) and the more or less extensive spotted white areas in some Greater Canada Geese, even though in the introduction two examples of medium extension white areas also surrounding the eye in presumed Greylag Geese were given.

\section{References}

Artportalen. web: http://www.artportalen.se/birds/gallery. asp? artid $=107$.

Gustavsson, C.G. 2009. Images of Barnacle Goose Branta leucopsis hybrids - a photo documentation of some crosses with different Anser species. Ornis Svecica 19: 19-31.

Gustavsson, C.G. 2010. Coloured tail-coverts in Anser $\times$ Branta goose hybrids despite all-white coverts in both parent species. Ornis Svecica 20: 67-75.

Gustavsson, C.G. web: http://www.artportalen.se/birds/gallery_imageinfo.asp?imageID $=21577$

Hanson, H.C. 1949. Notes on white spotting and other plumage variations in geese. Auk 66: 164-171.

Harteman, J. web: http://www.harteman.nl/omnibus/anseriformes/images/species/Branta_canadensis_maxima-01. jpg and

http://www.harteman.nl/omnibus/anseriformes/images/spe- 
cies/Branta_canadensis_maxima-02.jpg

Madge, S. \& Burn, H. 1988. Wildfowl. Christopher Helm (Publishers) Ltd, London.

Randler, C. 2001. Field identification of hybrid waterfowl Geese. Alula 7: 42-8.

Södercrantz, J. web: http://www.artportalen.se/birds/gallery_imageinfo.asp?image $\mathrm{ID}=7033$

\section{Sammanfattning}

Ett vitt område framtill på huvudet är typiskt för bläsgås och fjällgås men vita fält förekommer också på adulta fåglar av ett flertal andra Anser-arter inklusive grågås Anser anser i form av en smal vit rand vid näbbroten (Madge \& Burn 1988). Även hos några procent av kanadagäss Branta canadensis finner man vita områden på huvudet, utöver den ljusa kindfläcken (Hanson 1949).

Avsikten med den här studien var att undersöka förekomst av och utbredning hos vita fält på huvudet hos hybrider grågås $\times$ kanadagås och jämföra med förekomsten hos föräldraarterna. Tjugo hybrider grågås $\times$ kanadagås jämfördes med 191 grågäss och totalt 125 kanadagäss från två separata material.

Förekomst alternativt avsaknad av vita fält på gässens huvud framgår av Tabell 1 . Ett vitt fält från näbbroten och med varierande utbredning framtill på huvudet förelåg således hos alla de $17 \mathrm{av}$ totalt 20 hybrider som uppfattades som adulta (tre uppfattades som 1k) men bara 82 av 191 adulta grågäss $(\mathrm{p}<0.001)$. De vita fälten på hybriderna var också större än hos de 82 grågäss som hade ett påvisbart vitt fält, enligt en skala minimalt-litet / medelstort / större vitt område var fördelningen hos hybrider- na 5 / 8 / 4 individer och hos grågässen 82 / 0 / 0 $(\mathrm{p}<0.001)$. Ett annat sätt att kvantifiera storleken på de vita fälten var att jämföra med det största vita fältet som fanns hos någon av grågässen; på hybriderna var de vita fälten då större i 12 fall och lika stort eller mindre i 5 fall $(\mathrm{p}<0,001)$.

De totalt 125 kanadagässen kom från två olika material: det ena omfattade 30 individer som insamlats för genetisk och morfologisk analys, det andra 95 individer som på en och samma lokal och vid samma tillfälle både studerades med kikare och fotograferades. I det första materialet hade en fågel ett avvikande vitt fält på huvudet och i det andra materialet hade 4 av 95 ett vitt fält. I båda fallen var vita fält hos hybriderna signifikant vanligare än hos kanadagässen ( $<<0,001$ gentemot båda materialen). Jämförelse av de vita fältens storlek hos hybrider och kanadagäss bedömdes inte meningsfylld på grund av det ringa antalet kanadagäss med vita teckningar.

Sammanfattningsvis är således vita teckningar kring näbbroten och framtill på huvudet vanligare hos hybriderna än hos föräldraarterna. Liksom hos grågässen ansluter de vita fälten till näbbkanten men de är större hos hybriderna. Det finns också ofta ett inslag av vitfläckighet som påminner om den som kan ses på kanadagäss och då mest på huvudets främre del. Enligt min bedömning har resultatet av den här studien dels ett principiellt intresse ur aspekten hur olika drag kan nedärvas hos hybrider, dels en fältbestämningskonsekvens eftersom de vita fälten på huvudet ibland felaktigt uppfattas som tecken på inslag av bläsgås. 